\title{
An Efficient Synthesis of 12-epi-Carbacyclins Using a Palladium-Mediated Tandem Alkene Insertion Strategy
}

\author{
Nam Ho Lee and Richard C. Larock ${ }^{\dagger}$ \\ Department of Chemistry: Cheju National Lniversity, Ara-1, Cheju 690-756, Korea \\ ${ }^{\dagger}$ Deparment of Chemistrv, Iow a State Cniversitv, Ames, LA 50011, U.S.A. \\ Received June 27, 2001
}

\begin{abstract}
A short șinthesis of novel prostanoids. 12-epi-carbaçclins 3 and 24 . has been accomplished using palladium chemistry as a key step. The silỵ lenol ether 10a prepared through organopalladium chemistry has been allowed to react with 1 -octen-3-one in the presence of $\mathrm{Pd}(\mathrm{OAc})$; to give compound 12 in a single step. The unusual chemo- and stereoselective reduction of the $\alpha, \beta$-unsaturated ketone in 12 has been effected with (S)-BINAL$\mathrm{H}$. Subsequent desilylation and Wittig reaction have provided the PGI 2 analogues $\mathbf{3}$ and $\mathbf{2 4}$.
\end{abstract}

Keywords : Prostacyclin. Carbacyclin. Palladium, Organic synthesis, Alkene insertion.

\section{Introduction}

Prostacyclin ( $\left.\mathrm{PGI}_{2}, 1\right)$ was discovered by Vane and coworkers in 1976, and its structure was subsequently determined by Johnson and co-workers at Upjohn in collaboration with the Vane group. = Once discovered. it was clearly recognized to have many clinical applications for the treatment of cardiovascular disease, because of its potent antiplatelet and vasodilating effect. However, prostacyclin's chemical instability due to enol ether hydrolysis has limited its pharmaceutical utility. Since its discovery. therefore. many attenipts have been made to develop chemically and metabolically stable $\mathrm{PGI}_{2}$ analogues. ${ }^{3}$
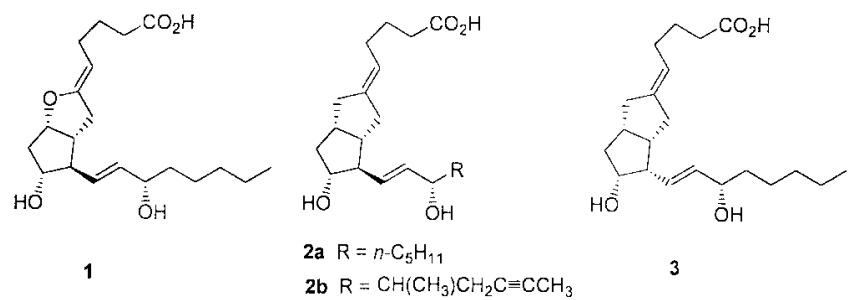

Among the stable $\mathrm{PGI}_{2}$ minics. carbacyclin (2a) and its analogues have attracted special attention. Carbacyclin, where prostacyclin's enolic oxygen is replaced by a methylene moiety, was first independently synthesized in 1978 by four groups. ${ }^{4}$ The compound $2 \mathrm{a}$ was found to have a phannacological profile similar to that of 1 . It is. for example, a potent inhibitor of platelet aggregation. a vasodialator and an inhibitor of gastric acid secretion." Even though $\mathbf{2 a}$ has failed to achieve clinical usage due to side effects. the $\omega$ chain modified carbacyclin analogue hlown as iloprost (2) has been utilized as a drug to treat peripheral vascular disease.

In our continuing effort to synthesize prostaglandins. ${ }^{7} 12$ epi-carbacyclin (3) appeared to be an interesting carbacyclin analogue that we might approach using organopalladiun chemistry (Scheme 1). ${ }^{8}$ Silyl enol ethers have previously been studied as organopalladium precursors leading to

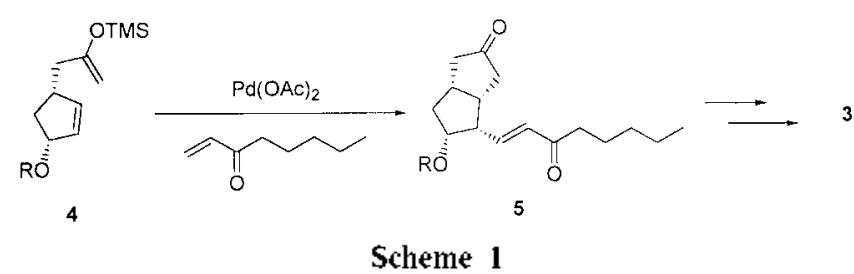

cyclization products via alkene insertion. ${ }^{9}$ The coupling of 1-octen-3-one and an organopalladium intermediate generated by the cyclization of compound 4 should give compound $\mathbf{5}$ in a single step. Subsequent reactions. including selective reduction of the $\alpha, \beta$-unsaturated ketone and a Wittig reaction should provide the novel $\mathrm{PGI}_{2}$ analogue in very few steps. Unlike all of the carbacyclin analogues previously synthesized. 3 has an all-cis configuration around the cyclopentane ring.

\section{Results and Discussion}

Organopalladium precursors 10a and $10 \mathrm{~b}$ have been prepared by the sequence shown in Scheme 2. Compound 7 was prepared stereoselectively from cyclopentadiene monoepoxide (6) and ethyl acetoacetate using $\pi$-allylpalladium
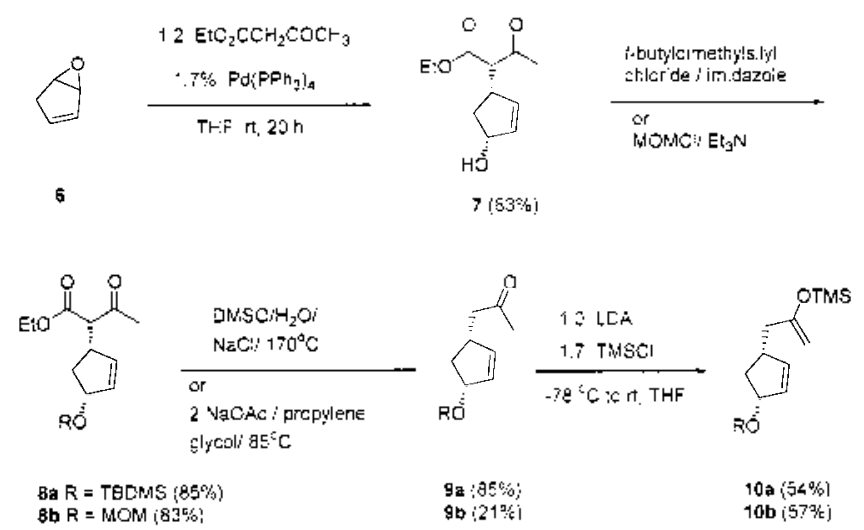

Scheme 2 
Table 1. Reaction conditions for synthesis of the carbacyclin framework using a palladium-mediated tandem alkene insertion strateg.

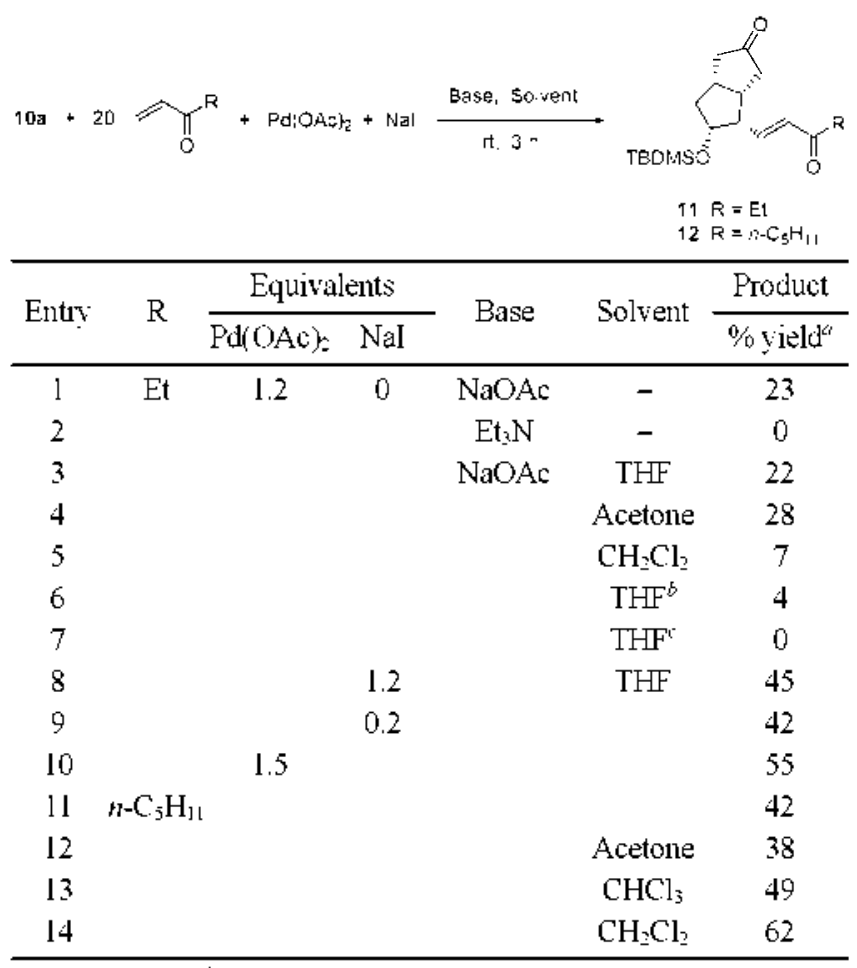

"Isolated vields. ${ }^{b} \mathrm{Li}_{2} \mathrm{PdCl}_{4}$ was used instead of $\mathrm{Pd}(\mathrm{OAc})={ }^{c} 1.0$ equiv. of $\mathrm{PPl}_{3}$ was added.

chemistry. ${ }^{10}$ The decarboalkoxylation of alcohol 7 using Krapcho's method ${ }^{11}$ provided only unidentified product possibly due to rearrangement of hydroxyl group. However. protection of the hydroxy group in compound 7. followed by thermal decarboalkoxylation, provided ketone $9 \mathrm{a}$ in $85 \%$ yield. Subsquent treatment of ketone 9a with LDA and trimethy lsilyl chloride ${ }^{12}$ afforded silyl enol ether 10a.

The key step for the synthesis of $\mathbf{3}$ was examined using enol silane 10a as the organopalladium precursor. Various reaction conditions were studied to effect the $\mathrm{Pd}(\mathrm{II})$-mediated cyclization and subsequent enone coupling as a singlestep procedure. The results are summarized in Table 1. As a model study, ethyl vinyl ketone (20 equiv.) which was easily removed after the reaction due to its volatility was first tried as an organopalladiun trapping agent. Previously we have developed a $\mathrm{Pd}(\mathrm{II})$-mediated tandem alkene insertion procedure $^{7 \mathrm{a}}$ for the synthesis of $12-e p i-\mathrm{PGF}_{2 \alpha}$. Accordingly we have first tried the previous reaction conditions, i.e. 1.2 equiv of $\mathrm{Pd}(\mathrm{OAc})_{2}$ and $\mathrm{NaOAc}$ as a base. with no solvent (entry 1). Using these conditions, the product 11 was obtained in only a $23 \%$ yield. An examination of a number of other bases. including $\mathrm{Na}_{2} \mathrm{CO}_{3}, \mathrm{~K}_{2} \mathrm{CO}_{3}$, and $\mathrm{LiOAc} \cdot 2 \mathrm{H}_{2} \mathrm{O}$ provided sinilar results, whereas an organic base. such as triethylamine, gave none of the desired product. In this reaction, usually the reduced product $9 \mathrm{a}$ and elimination product 15 were obtained as side-products (Scheme 3). For example, $9 \mathrm{a}$ and 15 were obtained in $20 \%$ and $5 \%$ yields respectively in the reaction shown in entry 1 . An exami-

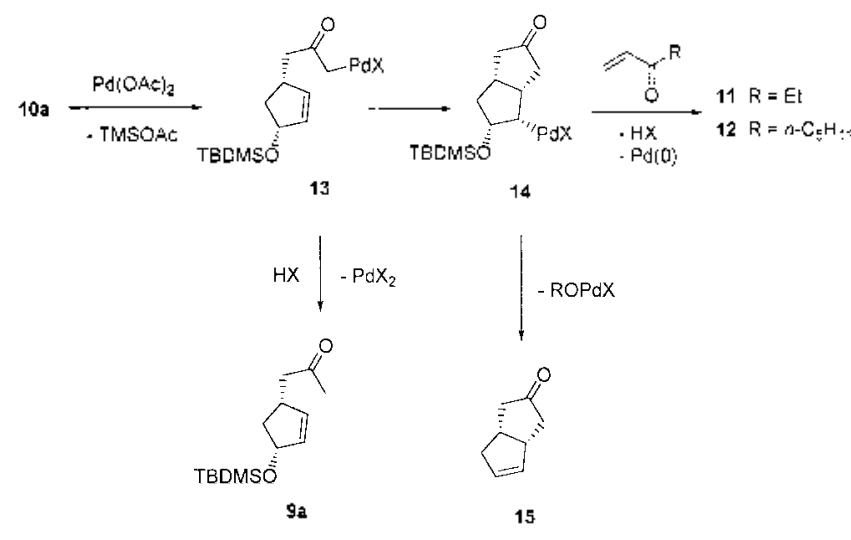

Scheme 3

nation of several solvents failed to improve product yields (entries 3-5). Switching the $\mathrm{Pd}(\mathrm{II})$ species from $\mathrm{Pd}(\mathrm{OAc})$, to $\mathrm{Li}_{-} \mathrm{PdCl}_{4}$ gave worse results (entry 6 ). Employing $\mathrm{PPh}_{3}$ as an additive gave none of the desired product, and $9 \mathrm{a}$ was obtained as the only product. This implies that $\mathrm{PPl}_{3}$ coordination to $\mathrm{Pd}(\mathrm{II})$ inhlibits cyclopentane coordination. which makes intramolecular organopalladium insertion difficult. Even though. employing different solvents did not make much difference in the product yield (entry 3 ), the sideproduct distribution was somewhat different from that obtained under neat reaction conditions. For example, compared to the result in entry 1.15 was obtained in higher yield $(44 \%)$ than $9(5 \%)$ when THF was employed as the solvent (entry 3). This implies that, under dilute conditions, the lowered HOAc concentration produces less of ketone 9. Also. lowered the enone concentration provides a higher chance of forming the elimination product 15 . For all of the above reactions (entries 1-7). some starting material 10a was observed to be converted to unidentified products, which resulted in a poor material balance $(\sim 60 \%)$ ).

While sily loxy palladium elimination in intermediate $\mathbf{1 4}$ appeared to be a major problem in this reaction. we decided to employ other protecting group in compound $\mathbf{1 0}$ to prevent the elimination. The MOM protecting group was considered to be a better choice. because the organopalladium intermediate $1+$ might be stabilized by the coordination of a nearby oxygen as in intermediate 16 . Then. the stabilized intermediate 16 might have sufficient time to undergo intermolecular enone insertion. However. that was not the case. The

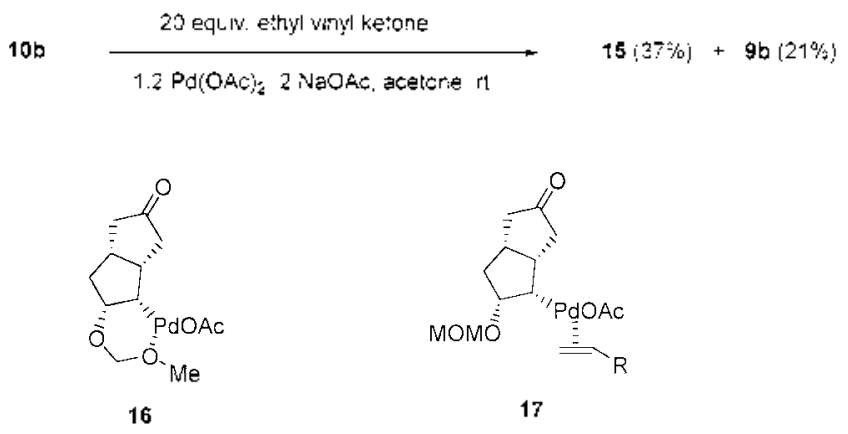

Scheme 4 
oxygen coordination appararently makes olefin coordination to form intermediate $\mathbf{1 7}$ more difficult. As a result, none of the desired product was obtained (Scheme 4).

Working on the other project on prostaglandins. we found it very interesting that none of eliminated product such as $\mathbf{2 0}$ was observed in our synthesis of the 12-epi-benzoprostacyclins (Eq. 1). ${ }^{70}$ The difference in the chenistry of organopalladium intermediates 14 and 18 may depend on the ligand present on palladium. Thus, we decided to change the ligand from acetate to iodide. The reaction was conducted simply by adding sodium iodide to the reaction mixture. By doing this. we observed considerable improvement in product yield (entry 8 ). Thus, product 11 was obtained in $45 \%$ yield compared to the $22 \%$. yield obtained without $\mathrm{NaI}$ (compare entries 3 and 8). A catalytic amount of sodium iodide provided a very similar result (entry 9). When we increased the amount of $\mathrm{Pd}(\mathrm{OAc})_{2}$ to 1.5 equiv., some intproventent in the yield of 11 was also observed (entry 10).
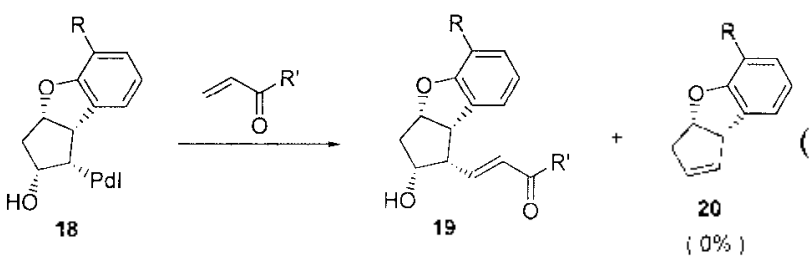

Now. the reaction was conducted with 1-octen-3-one, instead of ethyl vinyl ketone, using the reaction conditions shown in entry 10. The desired product 12 was obtained in $42 \%$ yield. The reaction was then examined using different bases and solvents. It was finally found that the reaction was best conducted in $\mathrm{CH}_{2} \mathrm{Cl}_{2}$ which afforded 12 in $62 \%$ yield (entry 14)

A reaction mechanism for this interesting tandem alkene insertion process is proposed in Scheme 3 . In the presence of $\mathrm{NaI}$. the reaction is considered to proceed first by a ligand exchange reaction (Eq. 2). Since the color change of $\mathrm{Pd}(\mathrm{OAc})_{2}$ from brown to a dark purple was inniediately observed as soon as $\mathrm{NaI}$ was added to the THF solution without any other substrates, one might suppose that the metathesis reaction in eq. 2 is occurring very fast.

$$
\mathrm{Pd}(\mathrm{OAc}) 2+\mathrm{NaI} \rightleftharpoons \mathrm{IPdOAc}+\mathrm{NaOAc}
$$

The treatment of precursor $10 a$ with a $\mathrm{Pd}(\mathrm{II})$ species should generate acyl palladium internediate 13. which can either cyclize to 14 or be protonated to 9 a depending on the reaction conditions. When $\mathrm{Et}_{\hat{j}} \mathrm{~N}$ or $\mathrm{PPh}_{\hat{j}}$ are present in the reaction mixture. they presumably coordinate to the $\mathrm{Pd}(\mathrm{II})$ in 13. preventing olefin coordination and thus favoring formation of compound 9a. The cyclized intermediate 14 can either couple with the enone to afford 12 (or 11) or undergo alkoxy-palladium elinination to produce enone $\mathbf{1 5}$. The ratio of 11 to 15 increased when adding $\mathrm{NaI}$, which intplies that the presence of the moiety PdI rather than PdOAc in 14 favors the alkene insertion. Presumably the more electrophilic palladium in the organopalladium acetate can more readily coordinate with the neighboring osygen moiety eventually producing the elimination product 15 .

To complete the synthesis of prostaglandin 3 . we needed to convert compound 12 to compound 21. For this conversion. we needed a method for the selective reduction of an $\alpha . \beta$-unsaturated ketone in the presence of a saturated ketone. Moreover. carbonyl reduction at $\mathrm{C}-15$ required a diastereoselectivity producing the (S)-alcohol. No general method was found to meet these requirements in the literature. ${ }^{13}$ So, we decided to examine Noyoris (S)-BINAL-H as a stereoand regioselective reducing agent. ${ }^{14}$ Even though BINAL-H has been well documented to reduce $\alpha, \beta$-unsaturated ketones stereoselectively in a predictable manner, no example has been reported where this reagent chemoselectively reduces enones in the presence of saturated ketones. However. we were pleased to observe that the stereo- and chemoselective reduction of compound $\mathbf{1 2}$ could be efficiently carried out using (S)-BINAL-H (Scheme 5). When compound 12 was subjected to reduction with (S)-BINAL-H. the desired product 21 was obtained selectively over compound 22 in a ratio of $9: 1$. The incidental overlap of compounds 21.22 and (S)-binaphthol on TLC made isolation of the product difficult. However. assignment of the olefunic hydrogens of compounds 21 and 22 in the crude product by ${ }^{1} \mathrm{H}$ NMR spectral analysis was possible. The olefinic hydrogens in compounds 21 and 22 have been compared to those in compounds $\mathbf{2 3}$ and $\mathbf{2 5}$, which could be isolated cleanly after desilylation. None of the over-reduced product $\mathbf{2 6}$ was observed upon ${ }^{1} \mathrm{H}$ NMR spectral analysis. Even though an excess of the reducing agent was employed, some of the starting material 12 was left upon ${ }^{1} \mathrm{H}$ NMR spectral analysis. Since the $R_{f}$ value of compound 12 was also close to $(S)$ binaphthol, no attempt was made to recover the starting material 12.
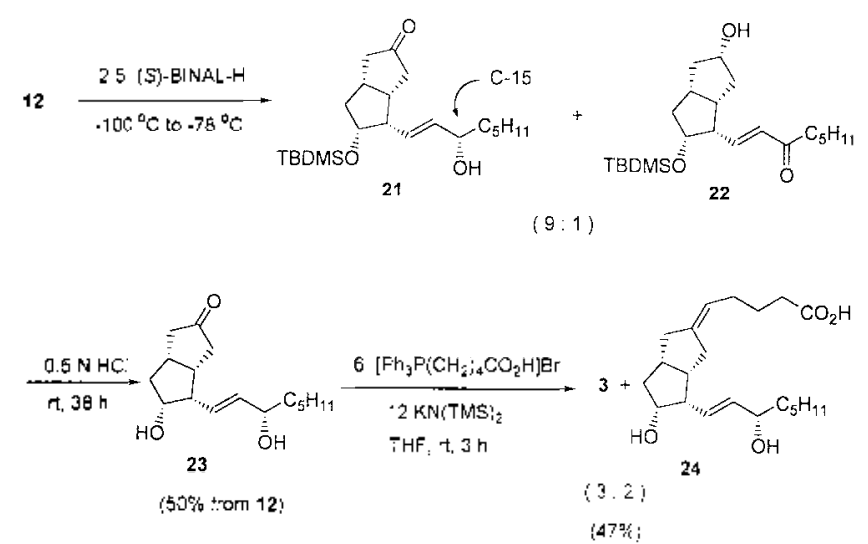

Scheme 5
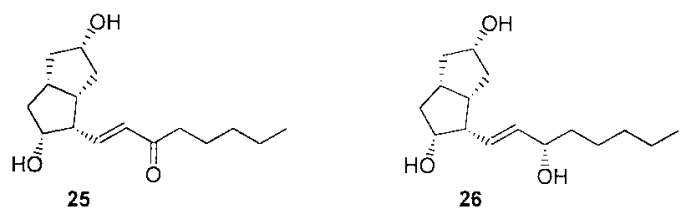
Deprotection of the silyl group in compound 21 was effected using aqueous hydrochloric acid to yield compound 23. which was then separable from (S)-binaphthol and compound 25. None of the C15-(R) isomer was observed. Since only one stereoisomer at $\mathrm{C}-15$ was obtained. we assigned it as the desired $\mathrm{Cl}$ - $(\mathrm{C})$ isomer based on a previous report where (S)-BINAL-H was used to effect a similar reduction. ${ }^{14}$ Therefore, compound $\mathbf{1 2}$ was reduced chemo- and stereoselectively to give crude product $\mathbf{2 3}$, which was, without further purification. subjected to hydrolysis to provide compound 23 in an overall $50 \%$ yield from compound 12.

A subsequent Wittig reaction on compound 23 provided the desired 12-epi-carbacyclin (3), along with its C5-Z isomer 24. The assignment of stereochemistry for these two compounds was based on the product ratio and the polarity of compounds 3 and 24 . A literature survey revealed that the $\mathrm{C} 5-\mathrm{E}$ isomer is always obtained as the major product upon Wittig reaction in analogous carbacyclin syntheses. ${ }^{1+}$ For example, in the synthesis of carbacyclin 2a, the C5-E isomer was obtained in about a $3: 1$ ratio over its $Z$ isomer upon Wittig reaction. ${ }^{4}$ In the case of $\mathbf{2 3}$, compound 3 was also obtained in larger amounts than conpound 24. We can explain this by proposing that the steric congestion in compound 3 is more favorable than that present in compound 24 . A literature survey ${ }^{15}$ also revealed that the more polar isomers are generally those with an E-configuration at $\mathrm{C}-5$ in sinilar prostaglandins. Compound 3 was obtained as the more polar isomer, which also supports our configurational assignment. Compounds $\mathbf{3}$ and $\mathbf{2 4}$ were characterized by ${ }^{1} \mathrm{H}$ NMR. ${ }^{13} \mathrm{C}$ NMR and IR spectroscopy, plus high resolution mass spectrometry.

In conclusion, a very efficient synthesis of the novel carbacyclins 3 and 24 has been accomplished using a palladium-promoted cyclization-tandem alkene insertion of an enol silane as the key step. The subsequent chemo- and stereoselective reduction of the resulting enone. and eventual Wittig reaction complete the process.

\section{Experimental Section}

General. All chenicals were used directly as obtained conmercially unless otherwise noted. Tetrahydrofuran was distilled over sodium benzophenone ketal and used immediately. Methylene chloride was distilled over phosphorous pentoxide and stored over $4 \AA$ molecular sieves. DMF was distilled over calcium hydride and stored over $+\mathcal{A}$ molecular sieves. Acetone was distilled over calcium hydride and stored over $+\hat{A}$ molecular sieves.

NMR spectra were recorded on a Nicolet NT-300 spectrometer ( ${ }^{1} \mathrm{H}$ NMR. $300 \mathrm{MHz} ;{ }^{13} \mathrm{C}$ NMR, $\left.75 \mathrm{MHz}\right)$. and chemical shifts are reported in ppm relative to TMS $(\delta 0.00)$ as an internal standard. The IR spectra were obtained on an IBM IR 98. High-Resolution mass spectra were recorded on a Kratos MS-50 spectrometer.

Preparation of 12-epi-carbacyclin (3). To a solution of (4-carboxybutyl)triphenylphosphonium bromide (Aldrich. dried for $12 \mathrm{~h}$ at $100^{\circ} \mathrm{C}$ under reduced pressure. $1.15 \mathrm{~g} .2 .66$ mumol) in $9 \mathrm{ml}$ of freshly distilled THF was added KHMDS (Aldrich. $0.5 \mathrm{M}$ in THF, $10.7 \mathrm{~mL} .5 .32 \mathrm{mmol}$ ) at room temperature under a $\mathrm{N}_{2}$ atmosphere. At this point, the reaction mixture turned a deep red color. The reaction mixture was stirred for $15 \mathrm{~min}$ at room temperature. To this was slowly added ketone 23 (118 $\mathrm{mg}, 0.44 \mathrm{nmol}$ ) in $2 \mathrm{ml}$ of THF. The reaction mixture turned a brown color. After stirring for $3 \mathrm{~h}$ at room temperature, the reaction was quenched by adding $\mathrm{H}_{2} \mathrm{O}(25 \mathrm{~mL})$. The reaction mixture was washed with ethyl acetate $(25 \mathrm{~mL})$ to remove any organic soluble side-product. The aqueous layer was acidified by adding $2 \mathrm{~N}$ aqueous $\mathrm{HCl}(2.4 \mathrm{~mL})$. The solution was extracted with $\mathrm{CH}_{3} \mathrm{Cl}_{2}(20 \mathrm{~mL} \times 3)$. The organic phase was washed with water $(15 \mathrm{~mL})$. then dried over anlydrous $\mathrm{MgSO}_{4}$ and concentrated. The crude product was purified by flash chromatography with $500: 1$ EtOAc/acetic acid to give compounds $3(44 \mathrm{mg})$ and $24(29 \mathrm{mg})$ as oils in an overall $47 \%$ yield. Compound $3: \mathrm{R}_{f}=0.3 \mathrm{l}(500: \mathrm{I} \mathrm{EtOAc} / \mathrm{AcOH})$; ${ }^{1} \mathrm{H}$ NMR $\left(\mathrm{CDCl}_{3}\right) \delta 5.66(\mathrm{dd}, J=15.3$ and $9.0 \mathrm{~Hz}, 1 \mathrm{H}$, $\mathrm{HC}=\mathrm{C}), 5.52(\mathrm{dd} . J=15.3$ and $6.6 \mathrm{~Hz}, \mathrm{H} . \mathrm{HC}=\mathrm{C}) .5 .16(\mathrm{t}, J$ $=6.9 \mathrm{~Hz}, \mathrm{lH}, \mathrm{HC}=\mathrm{C}) .4 .63($ br s, $2 \mathrm{H}, \mathrm{OH} s), 4.09(\mathrm{~m}, 2 \mathrm{H})$, $2.71-2.45(\mathrm{~m}, 3 \mathrm{H}), 2.45-2.23(\mathrm{~m}, 5 \mathrm{H}), 2.23-2.08(\mathrm{~m}, 2 \mathrm{H})$, $2.08-1.95(\mathrm{~m}, 2 \mathrm{H}), 1.78-1.63(\mathrm{~m}, 2 \mathrm{H}), 1.63-1.42(\mathrm{~m}, 3 \mathrm{H})$, $1.42 \cdot 1.18(\mathrm{~m}, 7 \mathrm{H}) .0 .89\left(\mathrm{t} . J=6.9 \mathrm{~Hz} \cdot 3 \mathrm{H} . \mathrm{CH}_{3}\right):{ }^{13} \mathrm{C}$ NMR $\left(\mathrm{CDCl}_{3}\right) \delta 177.87,144.71,136.69 .129 .18,119.96 .76 .92$. $73.18,51.33,44.50,41.49,40.54$. 37.07. 36.04. 35.80. $33.50,31.80 .28 .79 .25 .26,24.74 .22 .71,14.12$; IR (neat) $3414(\mathrm{OH}) .2930,2858.1709(\mathrm{C}=0), 1437 \mathrm{~cm}^{-1}$ : HRMS m/z 332.23463 [calculated for $\mathrm{C}_{21} \mathrm{H}_{32} \mathrm{O}_{3} \quad\left(\mathrm{M}-\mathrm{H}_{2} \mathrm{O}\right)^{+} . \quad \mathrm{m} / \mathrm{z}$ 332.23515]; Ammonia CI Mass, $\mathrm{m} / \mathrm{z} 368.2$ for $\mathrm{M}^{+}+\mathrm{NH}_{4}$. Anal. Calcd for $\mathrm{C}_{21} \mathrm{H}_{34} \mathrm{O}_{4}:$ C. 71.96: H, 9.78. Found: $\mathrm{C}$, 70.19: H, 8.77. Compound 24: $\mathrm{R}_{f}=0.38(500: 1 \mathrm{EtOAC}$ $\mathrm{AcOH}) ;{ }^{1} \mathrm{H}$ NMR $\left(\mathrm{CDCl}_{3}\right) \delta 6.00($ br s, $2 \mathrm{H}, \mathrm{OH}$ 's), $5.69(\mathrm{dd}$, $J=15.3$ and $7.8 \mathrm{~Hz}, 1 \mathrm{H} . \mathrm{HC}=\mathrm{C}$ ) 5.57 (dd. $J=15.3$ and 6.3 Hz. $\mathrm{lH}, \mathrm{HC}=\mathrm{C}) .5 .19(\mathrm{t}, J=7.2 \mathrm{~Hz} . \mathrm{lH}, \mathrm{HC}=\mathrm{C}) .4 .12(\mathrm{~m}$, $2 \mathrm{H}) .2 .64-1.95(\mathrm{~m}, \mathrm{l} 2 \mathrm{H}) .1 .78-1.25(\mathrm{~m}, 1 \mathrm{lH}), 0.88(\mathrm{t} . J=6.6$ Hz. $\left.3 \mathrm{H}_{2} \mathrm{CH}_{3}\right) ;{ }^{13} \mathrm{C} \mathrm{NMR}\left(\mathrm{CDCl}_{3}\right) \delta 178.90 .144 .57 .136 .22$. 129.69, 119.96. 76.47. 73.26, 51.28. 45.83, 41.45. 40.32, $37.05,33.27,31.81 .30 .29 .28 .55,26.42 .25 .25 .24 .54$, 22.69, 14.15; IR (neat) $3425(\mathrm{OH}), 1710(\mathrm{C}=0) \mathrm{cm}^{-1}$; HRMS $\mathrm{m} / \mathrm{z} 332.23470$ [calculated for $\mathrm{C}_{21} \mathrm{H}_{32} \mathrm{O}_{3}\left(\mathrm{M}-\mathrm{H}_{2} \mathrm{O}\right)^{-}, 332.235 \mathrm{l} 5$ ]: Ammonia $\mathrm{CI}$ Mass, $\mathrm{m} / \mathrm{z} 368.4$ for $\mathrm{M}^{-}+\mathrm{NH}_{4}$. Anal. Calcd for $\mathrm{C}_{21} \mathrm{H}_{34} \mathrm{O}_{4}: \mathrm{C}, 71.96: \mathrm{H}, 9.78$. Found: C. 67.63; H. 9.93 .

Preparation of compound 7. Cyclopentadiene monoepoxide (6.4.9 g. $60 \mathrm{mmol}$ ) dissolved in $10 \mathrm{~mL}$ of THF was added to a solution of $\mathrm{Pd}\left(\mathrm{PPh}_{3}\right)_{4}(1.18 \mathrm{~g} .1 .0 \mathrm{mmol})$ and ethyl acetoacetate $(9.4 \mathrm{~g} .72 \mathrm{mmol})$ in $50 \mathrm{~mL}$ of THF dropwise over $20 \mathrm{~min}$ at $0^{\circ} \mathrm{C}$. After stirring for $40 \mathrm{~min}$ at 0 ${ }^{\circ} \mathrm{C}$, the misture was allowed to warm to room temperature, then stirring was continued for $24 \mathrm{~h}$ at room temperature. The reaction mixture was concentrated in vacto, and the crude product was purified by flash chromatography using $1: 1$ hexane/EtOAc to give compound 7 as an inseparable mixture of diastereomers: $10.6 \mathrm{~g} .83 \%$ yield: $\mathrm{R}_{f}=0.25(\mathrm{l}: \mathrm{l}$ hexane/EtOAc); ${ }^{\prime} \mathrm{H} \mathrm{NMR}\left(\mathrm{CDCl}_{3}\right) \delta 5.82(\mathrm{~m} .2 \mathrm{H}, \mathrm{HC}=\mathrm{CH})$, $4.72(\mathrm{~m} . \mathrm{HH}) .4 .19$ (dq. $J=1.8$ and $7.2 \mathrm{~Hz}, 2 \mathrm{H}), 3.53(\mathrm{dd}, J=$ 
8.1 and $6.0 \mathrm{~Hz} . \mathrm{lH}), 3.26(\mathrm{~m} . \mathrm{HH}), 2.52(\mathrm{dt}, J=17.1$ and 7.8 Hz, IH). 2.23 (ddt. $J=42.3$ and 14.1 and $3.9 \mathrm{~Hz}, \mathrm{IH}$ ). 2.24 (s. $3 \mathrm{H}) .1 .44$ (dd, $J=4.8$ and $7.8 \mathrm{~Hz}, \mathrm{lH}) .1 .26$ (t. $J=6.9 \mathrm{~Hz}$. $\left.3 \mathrm{H}, \mathrm{CH}_{\hat{3}}\right) ;{ }^{13} \mathrm{C}$ NMR $\left(\mathrm{CDCl}_{3}\right) \delta 202.36,169.08,168.72$. 135.62. 135.29. 134.80. 134.31. 76.49. 64.59. 64.43, 61.52. $43.43,43.22 .38 .02 .37 .28,30.08 .29 .72 .14 .13:$ IR (neat) $3+23(\mathrm{OH}), 1715(\mathrm{C}=0) \mathrm{cm}^{-1}$.

Preparation of compound 8a. To a solution of alcohol 7 $(2.90 \mathrm{~g} .13 .7 \mathrm{mmol})$ and inidazole (2.33 g. $34.3 \mathrm{mmol})$ in 20 $\mathrm{mL}$ of DMF was added with stirring at room temperature $t$ butyldimethylsilyl chloride ( $2.27 \mathrm{~g}, 15.1 \mathrm{mmol}$ ) dissolved in $16 \mathrm{~mL}$ of DMF. After stirring for $\mathrm{I} t \mathrm{~h}$ at room temperature. the reaction was quenched by adding $20 \mathrm{~mL}$ of $\mathrm{H}_{2} \mathrm{O}$. The mixture was extracted with hexane $(50 \mathrm{~mL} \times 3)$, and the organic phase was washed with brine $(50 \mathrm{~mL})$, then dried and concentrated. The residue was purified by flash chromatograply using $4: 1$ hexane/EtOAc to give compound $8 \mathrm{a}: 4.27$ g. $96 \%$ yield; $\mathrm{R}_{f}=0.53$ (4: I hexane/EtOAc): ${ }^{1} \mathrm{H}$ $\mathrm{NMR}\left(\mathrm{CDCl}_{3}\right) \delta 5.79(\mathrm{~m}, 2 \mathrm{H} . \mathrm{HC}=\mathrm{CH}) .4 .79(\mathrm{~m}, \mathrm{lH}) .4 .20$ (q. $J=7.2 \mathrm{~Hz}, 2 \mathrm{H}$ ). $3.48(\mathrm{dd} . J=10.5$ and $3.6 \mathrm{~Hz}, 1 \mathrm{H}) .3 .24$ (m. $\mathrm{lH}), 2.40(\mathrm{~m}, \mathrm{lH}) .2 .24$ (s. $3 \mathrm{H}), 1.27(\mathrm{~m}, 4 \mathrm{H}) .0 .88$ (s. $9 \mathrm{H}, t-\mathrm{BuSi}) .0 .06\left(\mathrm{~s}, 6 \mathrm{H}, \mathrm{SiMe}_{2}\right)$.

Preparation of compound $8 \mathrm{~b}$. To a solution of alcohol 7 $(1.0 \mathrm{~g} .4 .7 \mathrm{mmol})$ and triethyl amine $(2.0 \mathrm{~mL}, 14.1 \mathrm{mmol})$ in $10 \mathrm{~mL}$ of THF was added MOMCl (Aldrich, $0.72 \mathrm{~mL} .9 .4$ $\mathrm{mmol}$ ) dropwise over $5 \mathrm{~min}$. After stirring for $9 \mathrm{~h}$ at room temperature, the mixture was filtered. and then concentrated. The residue was purified by flash chromatography to give compound $9 \mathrm{a}: 1.04 \mathrm{~g} .83 \%$ yield: $\mathrm{R}_{f}=0.52(\mathrm{l}: \mathrm{I}$ hexane/ EtOAc); ${ }^{1} \mathrm{H}$ NMR $\left(\mathrm{CDCl}_{3}\right) \delta 5.90(\mathrm{~m}, 2 \mathrm{H}), 4.85$ (m. $\left.3 \mathrm{H}\right)$. 4.20 (q. $J=7.2 \mathrm{~Hz} .2 \mathrm{H}) .3 .45(\mathrm{dd}, J=10.5$ and $5.4 \mathrm{~Hz}, \mathrm{lH}$ ). $3.35(\mathrm{~d}, J=2.1 \mathrm{~Hz} .3 \mathrm{H}) .3 .30(\mathrm{~m}, \mathrm{lH}) .2 .47(\mathrm{~m}, \mathrm{lH}), 2.24(\mathrm{~s}$. $3 \mathrm{H}), 1.4 \mathrm{l}(\mathrm{m} . \mathrm{lH}), 1.27(\mathrm{t} . J=7.2 \mathrm{~Hz} .3 \mathrm{H})$.

Preparation of compound 9a. To a round bottomed flask attached with a reflux condenser were placed compound $\mathbf{8 a}$ $(6.7 \mathrm{~g}, 20.6 \mathrm{mmol})$. DMSO $(20.6 \mathrm{ml}) . \mathrm{H}_{2} \mathrm{O}(1.1 \mathrm{~mL})$ and $\mathrm{NaCl}(1.8 \mathrm{~g} .31 .0 \mathrm{mmol})$. The reaction was placed in a hot oil bath $\left(165-170^{\circ} \mathrm{C}\right)$. and stirring was continued for $9 \mathrm{~h}$. The mixture was cooled to room temperature. then poured into $150 \mathrm{~mL}$ of diethyl ether. The phases were separated. and the organic phase was washed with water $(3 \times 30 \mathrm{~mL})$ and brine $(30 \mathrm{~mL})$. After being dried and concentrated in vacuo. the reaction mixture was purified by flash chromatography to give compound $9 \mathrm{a}$ as a colorless oil $4.44 \mathrm{~g}, 85 \%$ yield; $\mathrm{R}_{f}$ $=0.50\left(4:\right.$ l hexane/EtOAc): ${ }^{1} \mathrm{H}$ NMR $\left(\mathrm{CDCl}_{3}\right) \delta 5.74(\mathrm{~m}$. $2 \mathrm{H}, \mathrm{HC}=\mathrm{CH}), 4.81(\mathrm{~m}, \mathrm{lH}, \mathrm{CHOSi}) .2 .95(\mathrm{~m} . \mathrm{lH}), 2.55$ $(\mathrm{m} .3 \mathrm{H}), 2.18\left(\mathrm{~s}, 3 \mathrm{H} . \mathrm{O}=\mathrm{CCH}_{3}\right) .1 .23$ (ddd. $J=13.2$ and 6.0 and $5.4 \mathrm{~Hz} . \mathrm{H}$ ). $0.89(\mathrm{~s}, 9 \mathrm{H}, t$-BuSi). 0.06 (s, 6H. SiMe $)$ ): ${ }^{13} \mathrm{C} \mathrm{NMR}\left(\mathrm{CDCl}_{3}\right) \delta 207.79,135.83 .134 .41,76.43 .50 .15$. $40.71,39.04 .30 .22 .25 .78,18.02,-4.75:$ IR (neat) 1718 $(\mathrm{C}=\mathrm{O}) \mathrm{cm}^{-1} ;$ HRMS $\mathrm{m} / \mathrm{z}$ calculated for $\mathrm{C}_{1_{4}} \mathrm{H}_{\llcorner} \leq \mathrm{O}_{-} \mathrm{Si} 253.16238$, found 253.16260.

Preparation of compound $9 \mathrm{~b}$. A mixture of anhydrous propane-1.2-diol $(16 \mathrm{~mL})$ and sodium methoxide $(343 \mathrm{mg}$. 6.4 mmol) was heated at $85^{\circ} \mathrm{C}$ for $15 \mathrm{~min}$. To this was added compound 8a (812 mig. $3.2 \mathrm{mmol})$ and heating was continued for $40 \mathrm{~min}$. The reaction mixture was cooled to room temperature and $\mathrm{H}_{2} \mathrm{O}(5 \mathrm{~mL})$ was added, and then the reaction mixture was extracted with ether $(30 \mathrm{~mL} \times 3)$. The organic phase was washed with saturated $\mathrm{NH}_{4} \mathrm{Cl}(20 \mathrm{~mL})$ and brine $(20 \mathrm{~mL})$. Concentration, followed by flash chromatography. gave product $9 \mathrm{~b}$ : $122 \mathrm{mg}, 21 \%$ yied: ${ }^{1} \mathrm{H}$ NMR (CDCl3) $\delta 5.86(\mathrm{~m}, 2 \mathrm{H}) .4 .67(\mathrm{~m}, 3 \mathrm{H}), 3.36(\mathrm{~s}, 3 \mathrm{H}), 2.99(\mathrm{~s}$, IH). $2.55(\mathrm{~s}, 3 \mathrm{H}), 2.13(\mathrm{~s} .3 \mathrm{H}), 1.35$ (dt. $J=13.8$ and $7.5 \mathrm{~Hz}$, IH).

Preparation of compound 10a. To a solution of disopropylamine ( $2.93 \mathrm{~mL}, 21.0 \mathrm{mmol}$ ) in $44 \mathrm{~mL}$ of THF was added $n$-BuLi (Aldrich. $2.5 \mathrm{M}$ in hexane. $6.99 \mathrm{~mL} .17 .5$ mmol) at $-78^{\circ} \mathrm{C}$. The resulting misture was stirred for $2 \mathrm{~min}$ at that temperature. To this was added ketone $9 \mathrm{a}(4.42 \mathrm{~g}$. $17.5 \mathrm{mmol}$ ) over $10 \mathrm{~min}$ under $\mathrm{N}_{2}$ at $.78{ }^{\circ} \mathrm{C}$. The solution was stirred for $\mathrm{l} \mathrm{h}$, then freshly distilled trimethylsilyl chloride $(3.78 \mathrm{~mL} .29 .7 \mathrm{mmol}$ ) was added over $10 \mathrm{~min}$. The solution was allowed to wam to room temperature and stirring was continued for an additional $1 \mathrm{~h}$. The reaction mixture was concentrated under vacuum pressure. then hexane was added and the $\mathrm{LiCl}$ solid precipitated was filtered off. After concentration, the residue was purified by vacuum distillation $\left(110^{\circ} \mathrm{C} / 0.6 \mathrm{~mm} \mathrm{Hg}\right)$ to give compound $10 \mathrm{a}$ as a light yellow oil: $3.1 \mathrm{~g} .54 \%$ yield; $\mathrm{R}_{f}=0.48(15: 1$ hexane/EtOAc); ${ }^{1} \mathrm{H}$ NMR $\left(\mathrm{CDCl}_{3}\right) \dot{\delta} 5.83(\mathrm{~m} . \mathrm{lH}, \mathrm{HC}=\mathrm{C})$, $5.69(\mathrm{~m}, \mathrm{lH}, \mathrm{HC}=\mathrm{C}) .4 .82(\mathrm{~m}, \mathrm{lH}, \mathrm{CHOSi}), 4.06(\mathrm{~m} .2 \mathrm{H}$, $\left.\mathrm{C}=\mathrm{CH}_{2}\right) .2 .74(\mathrm{~m} . \mathrm{lH}), 2.37(\mathrm{dt}, J=13.2$ and $7.5 \mathrm{~Hz} . \mathrm{lH})$, 2.18 (dd, $J=13.8$ and $6.97 \mathrm{~Hz} .1 \mathrm{H}$ ), $2.03(\mathrm{dd}, J=13.8$ and $8.1 \mathrm{~Hz}, \mathrm{lH}$ ), 1.32 (dt. $J=13.2$ and $6.3 \mathrm{~Hz} .1 \mathrm{H}$ ). $0.90(\mathrm{~s}, 9 \mathrm{H}$, t-BuSi), 0.21 (s, 9H. $\mathrm{SiMe}_{3}$ ). 0.08 (s. $6 \mathrm{H}, \mathrm{SiMe}_{2}$ ); ${ }^{13} \mathrm{C}$ NMR $\left(\mathrm{CDCl}_{3}\right) \delta 158.11,136.80,133.99 .90 .86,77.55 .43 .47$, $41.68,40.67 .26 .05 .18 .33 .0 .23,-4.47$ : IR (neat) 2957, 2930 . $1252 \mathrm{~cm}^{-1}$ : HRMS calculated for $\mathrm{C}_{17} \mathrm{H}_{13} \mathrm{O}_{2} \mathrm{Si}_{2} 326.20974$. found 326.20917

Preparation of compound $10 \mathrm{~b}$. To a solution of LDA (0.65 numol) was added compound $9 \mathrm{~b}$ (120 $\mathrm{mg} .0 .65 \mathrm{mmol})$ at $-78^{\circ} \mathrm{C}$. After stirring for $\mathrm{l} \mathrm{h}$ at that temperature, TMSCl was added at $-78{ }^{\circ} \mathrm{C}$. The reaction mixture was warmed to room temperature. and stirring was continued for an additional $2 \mathrm{l}$. The reaction mixture was concentrated. and then hexane was added and the $\mathrm{LiCl}$ solid which precipitated was filtered off. After concentration and flash chromatography using 4:1 hexane/EtOAc, compound 10b was obtained: $96 \mathrm{mg} .57 \%$ yield; $\mathrm{R}_{f}=0.52$ (4: 1 hexane/EtOAc): ${ }^{1} \mathrm{H}$ NMR $\left(\mathrm{CDCl}_{3}\right) \delta 5.93$ (m. lH. $\left.\mathrm{C}=\mathrm{CH}\right), 5.80(\mathrm{~m}, \mathrm{lH}$, $\mathrm{HC}=\mathrm{C}), 4.69(\mathrm{~m} .3 \mathrm{H}), 4.06(\mathrm{~s}, 2 \mathrm{H}), 3.37(\mathrm{~s}, 3 \mathrm{H}) .2 .78(\mathrm{~m}$, IH). $2.42(\mathrm{dt}, J=13.8$ and $7.5 \mathrm{~Hz}, \mathrm{lH}$ ), 2.18 (dd. $J=13.2$ and $6.9 \mathrm{~Hz} . \mathrm{lH}), 2.04(\mathrm{~m} . \mathrm{lH}), 1.44($ dt. $J=13.5$ and $5.1 \mathrm{~Hz}$, 1H). 0.22 (s. 9 H. SiMe s. $^{2}$.

Compound 11. $R_{f}=0.27\left(3: 1\right.$ hexane/EtOAc); ${ }^{1} \mathrm{H}$ NMR $\left(\mathrm{CDCl}_{3}\right) 6.95(\mathrm{dd}, J=16.2$ and $8.7 \mathrm{~Hz} . \mathrm{lH}, \mathrm{HC}=\mathrm{CHCO})$, 6.12 (d. $J=16.2 \mathrm{~Hz} .1 \mathrm{H}, \mathrm{HC}=\mathrm{CHCO}), 4.29(\mathrm{~m} . \mathrm{lH}$, CHOSi). $2.94(\mathrm{~m} .2 \mathrm{H}), 2.69(\mathrm{~m}, \mathrm{lH}) .2 .59(\mathrm{~m} .4 \mathrm{H}), 2.25(\mathrm{~m}$. $3 \mathrm{H}) .1 .65(\mathrm{~m}, \mathrm{lH}), 1.10\left(\mathrm{t} . J=7.2 \mathrm{~Hz}, 3 \mathrm{H}, \mathrm{CH}_{3}\right) .0 .85(\mathrm{~s} .9 \mathrm{H}$, $t$ - $\mathrm{BuSi}), 0.02\left(\mathrm{~s}, 6 \mathrm{H} . \mathrm{SiMe}_{2}\right):{ }^{13} \mathrm{C}$ NMR $\left(\mathrm{CDCl}_{3}\right) \delta 219.57$, $200.79,145.02,132.05,78.43,51.94 .46 .32 .44 .15,43.74$. $40.16,38.18,32.58,25.74,18.04 .8 .22,-4.63$ : IR (neat) 2955. $1748(\mathrm{C}=\mathrm{O}), 1674(\mathrm{C}=\mathrm{O}), 1256 \mathrm{~cm}^{-1}$. HRMS $\mathrm{m} / \mathrm{z} 321.18885$ 
[calculated for $\mathrm{C}_{18} \mathrm{H}_{\unlhd} \mathrm{O}_{3} \mathrm{Si}\left(\mathrm{M}-\mathrm{CH}_{3}\right)^{-}, 321.18860$ ].

Preparation of compound 12. In a vial were placed compound 10a (256 mg. $0.78 \mathrm{~mm}$ ol). 1-octen-3-one (2.3 $\mathrm{mL}$. $16 \mathrm{mmol}) . \mathrm{K}_{2} \mathrm{CO}_{3}(216 \mathrm{mg} .1 .6 \mathrm{mmol}) . \mathrm{NaI}$ ( $23 \mathrm{mg}$. $0.16 \mathrm{mmol})$ and $\mathrm{CH}_{2} \mathrm{Cl}_{2}(2.3 \mathrm{~mL})$. The resulting misture was stirred for $2 \mathrm{~min}$ at room temperature. To this was added $\mathrm{Pd}(\mathrm{OAc})=(263 \mathrm{mg}, 1.2 \mathrm{mmol})$, then stirring was continued for $2 \mathrm{~h}$ at room temperature. After the reaction mixture was filtered through a silica gel pad using $\mathrm{I}: \mathrm{I}$ hexane/EtOAc, it was concentrated under reduced pressure. The residue was purified by flash chromatography with $3: 1$ hexane/EtOAc to give compound 12 as a yellow oil: $179 \mathrm{mg} .62 \%$ yield: $\mathrm{R}_{f}$ $=0.21\left(3: 1\right.$ hexane/EtOAc): ${ }^{1} \mathrm{H} \mathrm{NMR}\left(\mathrm{CDCl}_{\mathrm{j}}\right) \delta 6.96(\mathrm{dd} . J$ $=16.2$ and $8.7 \mathrm{~Hz} .1 \mathrm{H}, \mathrm{HC}=\mathrm{CHCO}), 6.11(\mathrm{~d} . J=16.2 \mathrm{~Hz}$. $1 \mathrm{H}, \mathrm{HC}=\mathrm{CHCO}) .4 .29(\mathrm{t} . J=3.9 \mathrm{~Hz} . \mathrm{lH}, \mathrm{CHOSi}), 2.94(\mathrm{~m}$. $2 \mathrm{H}), 2.70(\mathrm{~m} . \mathrm{lH}), 2.61(\mathrm{~m} . \mathrm{lH}) .2 .53(\mathrm{dt}, \mathrm{J}=2.4$ and $7.2 \mathrm{~Hz}$. $2 \mathrm{H}), 2.30-2.20(\mathrm{~m}, 3 \mathrm{H}) .1 .67-1.55$ (n. $3 \mathrm{H}), 1.34-1.22(\mathrm{~m}$, $5 \mathrm{H}), 0.88\left(\mathrm{t}, J=6.3 \mathrm{~Hz}, 3 \mathrm{H}, \mathrm{CH}_{3}\right) .0 .85(\mathrm{~s}, 9 \mathrm{H}, t-\mathrm{BuSi}), 0.01$ (s. $\left.6 \mathrm{H}, \mathrm{SiMe}_{2}\right){ }^{13} \mathrm{C} \mathrm{NMR}\left(\mathrm{CDCl}_{3}\right) \delta 219.42,200.47 .145 .08$. 132.23. 78.36. 60.30. 51.84, 46.23, 43.67, 40.05. 39.38 . $36.10,31.45,25.66,23.93 .22 .41,17.96,13.90,-4.74 ; \mathrm{IR}$ (neat) 2957. 2930. $1740(\mathrm{C}=\mathrm{O}) .1672(\mathrm{C}=\mathrm{O}) .1464,1364$ $\mathrm{cm}^{-1} ;$ HRMS m/z 377.25070 [calculated for $\mathrm{C}_{23} \mathrm{H}_{37} \mathrm{O}_{3} \mathrm{Si}$ (M$\mathrm{H})^{-} . \mathrm{m} / \mathrm{z}$ 377.25 119]: Amunonia CI Mass. m/z 396.3 for $\mathrm{M}^{+}$ $+\mathrm{NH}_{4}$.

Compound 15. $\mathrm{R}_{f}=0.46\left(3: \mathrm{I}\right.$ hexane/EtOAc); ${ }^{1} \mathrm{H}$ NMR $\left(\mathrm{CDCl}_{3}\right) \delta 5.82(\mathrm{~m} .1 \mathrm{H}, \mathrm{HC}=\mathrm{C}), 5.72(\mathrm{~m} . \mathrm{HH}, \mathrm{C}=\mathrm{CH}), 3.40$ (m. $1 \mathrm{H}$ ), 2.95 (m. $1 \mathrm{H}$ ). 2.69 (ddt. $J=16.5$ and 5.1 and 2.4 Hz, 1H). 2.47 (m. 2H). $2.2 \mathrm{l}$ (m. 2H). 1.98 (dd. $J=18.9$ and $6.9 \mathrm{~Hz}, \mathrm{IH}):{ }^{13} \mathrm{C}$ NMR $\left(\mathrm{CDCl}_{3}\right) \delta 220.49 .134 .07,130.43$. $46.31,44.93,42.67 .40 .15,37.12$; IR (neat) 2928, 2903. $1742(\mathrm{C}=\mathrm{O}), 1402.1159 \mathrm{~cm}^{-1}$.

Preparation of compound 23. To a solution of $\mathrm{LiAlH}_{4}$ (Aldrich, $1.0 \mathrm{M}$ in THF. $0.6 \mathrm{~mL} .0 .6 \mathrm{mmol}$ ) was added ethanol (2.0 M in THF. $0.3 \mathrm{ml}, 0.6 \mathrm{mmol}$ ) dropwise over 10 $\mathrm{min}$ at room temperature. Subsequently a THF solution of (S)-binaphthol (Aldrich. $170 \mathrm{mg}$ in $1 \mathrm{~mL}$ of THF. 0.60 $\mathrm{mmol}$ ) was added dropwise, and the resulting mixture was stirred for $30 \mathrm{~min}$ at room temperature, Enone $12(9 \mathrm{lmg}$. $0.24 \mathrm{mmol}$ ) in $1 \mathrm{~mL}$ of THF was added dropwise over $3 \mathrm{~min}$ at $-100{ }^{\circ} \mathrm{C}$ (liquid $\mathrm{N}_{2}$ and methanol bath). The reaction mixture was stirred for $2 \mathrm{~h}$ at $-100^{\circ} \mathrm{C}$, and then another $2 \mathrm{~h}$ at $-78^{\circ} \mathrm{C}$. Methanol $(\mathrm{ImL})$ was added at $-78^{\circ} \mathrm{C}$ to destroy the excess reducing agent and the reaction mixture was allowed to warn to room temperature. After the addition of water ( 25 $\mathrm{mL}$ ) and diethyl ether $(30 \mathrm{~mL})$, stirring was continued for 10 min. The reaction solution was neutralized with $2 \mathrm{~N} \mathrm{HCl}$. and then extracted with ether $(30 \mathrm{~mL} \times 3)$. The organic phase was dried over anlydrous $\mathrm{MgSO}_{4}$ and concentrated in verto. Crude product $(247 \mathrm{mg}$ ) was obtained. The relative product ratio was calculated using ${ }^{l} \mathrm{H}$ NMR spectroscopy by integration of the following characteristic peaks: compound 12. 6.09 ppin (d, $J=15.9 \mathrm{~Hz}, \mathrm{C}=\mathrm{CH}-\mathrm{C}=\mathrm{O})$ ) compound 21 . $5.77 \mathrm{ppm}$ (dd. $J=15.6$ and $8.1 \mathrm{~Hz}, \mathrm{HC}=\mathrm{C}$ ): compound 22 . $6.06 \mathrm{ppm}(\mathrm{d}, J=15.6 \mathrm{~Hz} . \mathrm{C}=\mathrm{CH}-\mathrm{C}=\mathrm{O})$. The product ratio of compounds 21 and 22 was calculated to be $9: 1$. The cride product was dissolved in $3 \mathrm{~mL}$ of THF. To this was added 3
$\mathrm{mL}$ of $0.5 \mathrm{~N}$ aqueous $\mathrm{HCl}$ at room temperature. After stirring for $38 \mathrm{~h}$ at room temperature, the misture was neutralized with $3 \mathrm{~N}$ aqueous $\mathrm{NaOH}$. Water $(7 \mathrm{~mL})$ was added to the mixture. After extraction with $\mathrm{CH}_{2} \mathrm{Cl}_{2}$, the organic phase was dried and concentrated. The residue was purified by flash chromatography to give compound 23: 32 mg. $50 \%$ overall yield: $\mathrm{R}_{f}=0.19\left(1: 2\right.$ hexane/EtOAc); ${ }^{1} \mathrm{H}$ $\operatorname{NMR}\left(\mathrm{CDCl}_{2}\right) \delta 5.72(\mathrm{dd}, J=15.3$ and $7.5 \mathrm{~Hz} . \mathrm{H}, \mathrm{HC}=\mathrm{C}$ ), 5.61 (dd, $J=15.3$ and $6.3 \mathrm{~Hz}, \mathrm{lH} . \mathrm{C}=\mathrm{CH}) .4 .29(\mathrm{~m}, \mathrm{lH}$, CHOH). 4.09 (q. $J=6.3 \mathrm{~Hz}, 1$ H. $\mathrm{CHOH}$ ). $2.88(\mathrm{~m}, 2 \mathrm{H}) .2 .68$ (dt, $J=4.5$ and $7.5 \mathrm{~Hz}, \mathrm{lH}$ ). $2.6 \mathrm{l}-2.5 \mathrm{l}(\mathrm{m} .2 \mathrm{H}$ ), $2.32-2.20$ (m. $3 \mathrm{H}$ ), 2.03 (br s, $2 \mathrm{H}, \mathrm{OH}$ 's). 1.61 (dt. $J=14.4$ and $3.0 \mathrm{~Hz}$, $1 \mathrm{H}) .1 .50(\mathrm{~m}, 2 \mathrm{H}), 1.29(\mathrm{~m}, 6 \mathrm{H}), 0.88(\mathrm{t}, J=6.6 \mathrm{~Hz} .3 \mathrm{H}$, $\left.\mathrm{CH}_{3}\right):{ }^{13} \mathrm{C}$ NMR $\left(\mathrm{CDCl}_{3}\right) \delta 221.40,136.80,128.41 .76 .83$, $72.91,51.17,46.38 .42 .20 .40 .49,37.33$. 36.97. 31.73, $25.15,22.60,14.05$ (one aliphatic carbon is missing due to overlap); IR (neat) $3404(\mathrm{OH}) .2930 .1734(\mathrm{C}=\mathrm{O}) .1458 \mathrm{~cm}^{-1}$; HRMS $\mathrm{m} / \mathrm{z}$ calculated for $\mathrm{C}_{16} \mathrm{H}_{26} \mathrm{O}_{3}$ 266.18819. found 266.18851 .

Compound 25. $\mathrm{R}_{f}=0.31$ ( $1: 2$ hexane/EtOAc); ${ }^{\mathrm{H}} \mathrm{H}$ NMR $\left(\mathrm{CDCl}_{3}\right) \delta 7.14$ (dd. $J=16.2$ and $7.8 \mathrm{~Hz}, \mathrm{lH}$. $\mathrm{HC}=\mathrm{CHCO}$ ). 6.69 (d. $J=16.2 \mathrm{~Hz} . \mathrm{lH}, \mathrm{C}=\mathrm{CH}-\mathrm{C}=\mathrm{O}), 4.32(\mathrm{~m} . \mathrm{H}$. $\mathrm{CHOH}$ ). $4.25(\mathrm{~m}, \mathrm{lH}, \mathrm{CHOH}) .3 .20$ (br s, lH. OH). $2.72(\mathrm{~m}$, $4 \mathrm{H}$ ). 2.59 (t. $\left.J=7.8 \mathrm{~Hz} .2 \mathrm{H}, \mathrm{O}=\mathrm{CCH}_{2}\right), 2.25$ (ddd. $J=15.0$ and 7.5 and $5.7 \mathrm{~Hz} .1 \mathrm{H}$ ). 2.14 (ddd. $J=13.8$ and 8.4 and 5.7 Hz. $\mathrm{lH}) .1 .98(\mathrm{~m}, \mathrm{lH}) .1 .88-1.79(\mathrm{~m}, 2 \mathrm{H}), 1.62(\mathrm{~m}, 2 \mathrm{H})$, $1.3 \mathrm{l}(\mathrm{m} .5 \mathrm{H}) .0 .89$ (t. J $=6.6 \mathrm{~Hz} .3 \mathrm{H} . \mathrm{CH}_{3}$ ).

Typical procedure for the reactions in Table 1 . In a vial were placed compound 10a ( $98 \mathrm{mg} .0 .30 \mathrm{mmol}$ ), ethyl vinyl ketone $(504 \mathrm{mg} .6 .0 \mathrm{mmol}), \mathrm{NaOAc}(82 \mathrm{mg} .0 .6 \mathrm{mmol}), \mathrm{NaI}$ $(9 \mathrm{mg}, 0.06 \mathrm{mmol})$ and THF $(1.8 \mathrm{~mL})$. The resulting mixture was stirred for $5 \mathrm{~min}$ at room temperature, then $\mathrm{Pd}(\mathrm{OAc})_{2}$ ( $81 \mathrm{mg}, 0.36 \mathrm{~mm}$ l) was added. After stirring for $2 \mathrm{~h}$ at room temperature, the reaction mixture was filtered through a silica gel pad. Concentration. followed by flash chromatography. gave compounds $9 \mathrm{a}, \mathbf{1 1}$. and $\mathbf{1 5}$.

\section{References}

1. Moncada. S.: Gryglewshi. R. T.: Bunting. S.: Vante. T. R. Natme 1976. 263,663 .

2. Jolnson. R. A.: Morton. D. R.: Kinner, J. H: Gorman, R. R.: McGuire. J. C.: Sun. F. F.: Whittaker, N.: Bunting. S.: Salmon, J.: Moncada. S.: Vane. T. R. Prostaglandins 1976. 12.915.

3. For recent papers related to synthesis of prostacyclin analogues. see: (a) Collins. P. W.: Djuric. S. W. Chem. Rev 1993. 93.1533. (b) Matsumura. Y.; Shimada. T.; Nakayama, T.: Urushihara, M.; Asai. T.: Morizawa. Y: Yasuda. Y. Tetrahedron 1995, 51,8771 (c) Node, M.: Inoue. T, Araki, M.: Nakamura, D. Tetrahedron: Astnmtetry 1998. 9. 157. (d) Negishi. E. I.: Pour. M.: Cederbaum. F. E.: Kotora. M. Tetrohedron 1998. 5+. 7057.

4. (a) Nicolaou. K. C.: Sipio. W. T.: Magolda. R. L.: Seits. S.: Barnett, W. E. J. Chem. Soc. Chem. Commun. 1978. 1067. (b) Kojima K.: Sakai, K. Tetrahedron Lett. 1978. 3743. (c) Shibasaki. M.; Ueda. J.: Ikegami. S. Tetohedron Lett. 1979, 433. (d) Morton Jr. D. R.: Brokaw. F. C. J. Org. Chent 1979. 4t. 2880.

5. (a) Whittle. B. J.: Moncada. S.: Whiting. F.: Vane. T. R. Prostaglandins 1980. 19. 605. (b) Aiket1. J. W: Shebuski. R. J. Prostaglandins $1980,19.629$. (c) Whittle, B. J. R.: Steel. G.; Boughton-Smith. N. K. J. Pham. Pharmacol. 1980. 32,603. 
6. (a) Skuballa. W: Vorbruggen, H. Angew (Them. Int. Ed. Engl. 1981. 20. 1046. (b) Stock. G.: Muller. B.: Krais. T.: Schillinger. E. Adv Prostaglandin. Thromboxane. Leukotriene Res. 1990. 10. 285.

7. (a) Larock. R. C.: Lee, N. H. J. Am. Chem. Soc. 1991, $113,7815$. (b) Larock. R. C. Lee, N. H. J. Org. (Them. 1991, 56, 6253. (c) Lee. N. H. Larock. R. C. Bull. Forean Chem. Soc, 1995, 16,859.

8. This results have been published as a communication. see: Larock. R. C.: Lee. N. H. Tetrahedron Lett. 1991. 32.5911.

9. (a) Ito. Y.: Aoyama. H.: Hirao. T.: Mochizuki. A.: Saegusa. T. . Am. Chem. Soc. 1979. 101. 494. (b) Ito, Y: Aovama. H.: Saegusa. T. J. Am. Chem. Soc. 1980, 102, 4519. (c) Kende. A. S.; Roth. B.; Sanfilippo. P. J. J. Am. Chem. Soc. 1982, 104. 1784. (d) Kende. A. S.: Roth. B.: Sanfilippo. P. J.: Black. T. J. J. Am. Chem. Soc. 1982. 104. 5808 .

10. (a) Trost. B. M.: Molander. G. M. J. Am. Chem. Soc. 1981. 103.
5969. (b) Deardorff. D. R: Myles. D. C.: Macferrin, K. D Tetwahedron Lett. 1985. 26.5615.

11. Krapcho. A. P. Stmhesis 1982. 893.

12. Fleming. I.: Paterson. L. Sinthesis 1979. 736.

13. For a study on the chemoselective, but not stereoselective. enone reduction at $\mathrm{C}-15$ in PGs in the presence of a saturated ketone. see: Green, A. E.; Teiveira. M. A.: Barreiro, E.: Cruz, A.: Crabbe. P. J. J. Ong Chem. 1982. 47. 2553.

14. (a) Noyori. R.: Tomio. I.: Tanimoto. Y.: Nishizawa. M. J. An. Chent. Soc. 1984. 106. 6709. (b) Noyori. R.: Tomio. I.: Yamada. M.: Nishizawa. M. J. Am. Chem. Soc. 1984. 106.6717.

15. (a) Sugie, A:; Shimomura. H: Katsube, J.: Yamamoto. H. Tetrahedron Lett. 1979, 2067. (b) Newton, R. F.: Wadsworth, A. d. Chent. Soc. Perkin Trans. I 1982. 823. (c) Skuballa. W. Tetrahedon Lett. 1980. 21.3261. 